\title{
European Patent Office rejects bid to revoke first plant patent
}

Munich. The European Patent Office (EPO) last week rejected an appeal by industrialists, environmentalists and farmers against its decision three years ago to grant the first European plant patent.

The patent, held by the US-based Lubrizol Corporation, covers any transgenic plant originally derived from a plant cell that has been tranfected with a plant gene under the control of a plant promoter, using the agrobacterium T-DNA as the gene-transfer system. An appeals board within the EPO rejected claims that the technical advance made by Lubrizol was insufficiently novel, and said that it has never been a generally accepted principle in Europe that patents may not be granted for plants. It also dismissed a range of moral objections which, it said, are outside its authority.

Opponents of the Lubrizol patent argue that patent laws that worked happily when the biological arena was confined to microbiological products do not fully come to terms with the complex possibilities offered by biotechnology. They also claim that the EPO's decision gives an unfair market advantage to the patent owner, whose innovative contribution they allege to be minimal. In addition, political interest groups are challenging the basic assumption that the EPO has the right to issue patents on any life-form.

Part of the patent, which claimed rights to the gene-transfer methodology itself, was cancelled because the appeal board agreed that the technology involved was of a general nature. Nevertheless, Lubrizol officials are pleased with the ruling and believe that it strengthens their application for a US patent. In confirming the patentability of plants, Lubrizol says, the EPO has addressed an issue important to all plant biotechnology companies.

All of the interest groups intend to appeal further against the patent. Unlike the US system, where the issued patent is final, European laws allow appeals to be heard after every decision in the process, provided that objections are lodged within nine months.

Further appeals from biotechnology companies, which are themselves applying for patents for transgenic plants, will challenge the modified Lubrizol patent on the grounds that it is based on a technique that they do not believe is innovative. Although it rejected the gene-transfer methodology itself as insufficiently novel to warrant a patent, the EPO ruled that the detection of the expressed gene is suitably novel to warrant patent coverage of all plant cell progeny. But opponents believe that this is simply an obvious corollary of the transfection process.
"We maintain that expression is not enough to support a claim of inventiveness", says Jan van Rompaey, patent manager at Belgium's Plant Genetic Systems and an adviser to the opposition groups. "Having shown that transfection can be achieved, it is fairly obvious that there would be a reasonable chance of transcription of the gene and detection of the product. This is not innovation."

The breadth of the coverage of the patent is also criticized by biotechnology companies. They claim that the rewards to Lubrizol are out of proportion to its scientific input, and that the patent unfairly restricts their own "freedom to operate". Edward Veltkamp, head of research and development for Sandoz Seeds in Basel, Switzerland, says that "a reasonable relationship should exist between the scope of the claims granted and the innovatory contribution delivered by the applicant." But EPO believes that there is no legal relationship between the two.

Environmentalists and other political interest groups are also unhappy about a recent reinterpretation by EPO of an article in the European Patent Convention (EPC), the rules that the EPO accepts as its guide, which excludes the patenting of any natural life-form. They say that its reinterpretation - which paved the way for Europe's first animal patent, the 'oncomouse' developed by Philip Leder of Harvard University (see Nature 353, 589 1991) - is an undemocratic decision affecting fundamental moral and environmental issues. They claim that the EPO does not have the right to make such a decision.

In the Lubrizol patent application, claims were acceptable to the EPO because they referred to plants and not the plant varieties specified in the EPC article. According to Harald Wosihnoj of Austria's Gen-ethisches Netzwerk, a collection of individuals and advocacy groups campaigning for the ethical use of genetic technology, these linguistic gymnastics undermine the EPC's aims.

As debates about life-form patenting gather momentum, opponents agree that the patent laws need to be refined to accommodate the issues raised by new biological technologies. They concede that the EPO has a difficult job in trying to apply rules formulated in the $1960 \mathrm{~s}$, before the advent of transgenic life-forms.

Alison Abbott

\section{US to seek gene patents in Europe}

Washington. The US National Institutes of Health (NIH) are this week expected to submit to the European Patent Office a controversial patent application on more than 2,000 cDNA fragments. Coming a year after NIH launched an international dispute with its first patent application for such gene sequences, the European filing is an "interim policy" that will keep NIH's options open while officials debate the alternatives, says Bernadine Healy, the NIH director.

Despite the protests of France, Britain and most of the scientific community, which opposes patents on gene sequences when a biological function is not known, the US government has not yet taken an official position. European patent law allows inventors to file for up to 12 months after a US filing without risk of losing the patent because of public disclosure. US officials appear receptive to the idea of an international treaty to resolve the issue, but no one has suggested what such a treaty should say or how it should be implemented.

Interviewed in Paris last month, Hubert Curien, the French science minister, said that the European Patent Office had assured him that such sequences were not patent- able. "I will be very sorry if this [attempting to patent in Europe] is what the United States decides", he said at the time.

Although French scientists have encouraged President François Mitterrand to raise the issue with the US president, George Bush, Curien said that he had already spoken to White House science adviser D. Allan Bromley, who defended patenting as a way to ensure publication. "I don't think that Mitterrand will get a different answer", Curien said.

In a related development, J. Craig Venter, the NIH scientist who sequenced the fragments that are the subject of the US patent application, was one of three dozen scientists who signed a resolution calling for an end to patents of "naturally occurring gene sequences" in favour of patents only on the uses of those sequences. Venter has said that he supported the NIH patent filing as a way to stimulate debate, but that he hopes the patent will not be granted. The statement, approved by participants in a South-North human genome conference held last month in Brazil, also calls for an international treaty. But it offers no details.

Christopher Anderson 